\title{
ECONOMY
}

\section{RESEARCH OF MULTIPLE INVESTMENT STRATEGIES USING A SHORT AND LONG POSITION}

\author{
Dr. Usef Al Mawadeh, Royal Hashemite Court, Jordan \\ DOI: https://doi.org/10.31435/rsglobal_ijite/30112019/6793
}

\section{ARTICLE INFO}

Received 12 September 2019 Accepted 10 November 2019

Published 30 November 2019

\section{KEYWORDS}

mathematical methods in economics; investment portfolio; equilibrium portfolio; optimal portfolio; inertial strategy; short position; long position. \begin{abstract}
The construction of an optimal portfolio of securities is one of the main tasks of managing the financial system, in which individual assets are only a component part. However, each asset also requires a separate study.

I gave the article building an investment portfolio with a zero strategy, comprising borrowing some assets and buying other assets for the same amount. The study comprised choosing the length of the historical horizon, the ranking criterion and the portfolio structure that ensured the maximum investor income.
\end{abstract}

Citation: Usef Al Mawadeh. (2019) Research of Multiple Investment Strategies Using a Short and Long Position. International Journal of Innovative Technologies in Economy. 6(26). doi: 10.31435/rsglobal_ijite/30112019/6793

Copyright: (C) 2019 Usef Al Mawadeh. This is an open-access article distributed under the terms of the Creative Commons Attribution License (CC BY). The use, distribution or reproduction in other forums is permitted, provided the original author(s) or licensor are credited and that the original publication in this journal is cited, in accordance with accepted academic practice. No use, distribution or reproduction is permitted which does not comply with these terms.

Introduction. The construction of an optimal portfolio of securities is one of the main tasks of managing the financial system, in which individual assets are only a component part. However, each asset also requires a separate study. I base inertial investment strategies on the assumption that the trend of the most profitable stocks in the past will continue, a similar assumption about the most unprofitable stocks. Therefore, in inertial strategies, the investor seeks to buy part of the most profitable shares and sell less profitable ones. Inertial strategies attract their simplicity. At the beginning of the development of such strategies, average profitability they used average profitability ranking criterion. In [1], various relations taking into account profitability and risk ranking criteria.

In this paper, three criteria were used to rank. The aim of the work was to determine the most effective criterion for a short-term ownership period of 30 days using real data not smoothed and smoothed by the Caterpillar-SSA method.

Statement of the problem.

The investment strategy under consideration is:

1. Asset ranking by the selected criterion.

2. The division of assets into "good" and "bad" according to the value of the criterion.

3. Simultaneous sale (short position) of "bad" assets for a certain amount and purchase (long position) for the same amount of "good" assets.

4. The formation of two portfolios of "good" and "bad" from the respective assets.

5. The definition of income of the investment strategy at the end of the ownership period, as the difference between the costs of "good" and "bad" portfolios.

The interval [t1, t2] will be called the historical horizon, $[\mathrm{t} 2, \mathrm{t} 3]$ the period of ownership.

Asset ranking. Denote by ri, $j$ the profitability of the $j$-th asset at the $i$-th moment in time. Consider the array of returns on the selected historical horizon. For each asset, we calculate the value of the selected criterion. Asset ranking is carried out according to three criteria: 
We define the mean criterion for a certain period as the average value of daily stock returns., this can be written:

$$
\mathrm{Sr}=\text { mean }(\mathrm{r})
$$

where mean $(r)$ - average values of returns for a certain period; r- daily yield.

The Sharp criterion uses average daily returns over a specified period. They define the values of the Sharp criterion:

$$
\text { Sharp }=\text { mean }(r) / \sigma \text {, }
$$

where mean (r) - average values of returns for a certain period;

$\sigma$ is the standard deviation or standard deviation.

Farinelli-Bialetti criterion:

where $\mathrm{E}(\mathrm{r})$ is the average return on an asset,

$$
\mathrm{FT}=\mathrm{E}(\mathrm{r}+) / \mathrm{E}(|\mathrm{r}-|)
$$

$\mathrm{r}+$ - positive asset returns,

$\mathrm{r}-\mathrm{-}$ negative asset returns.

\section{The formation of two portfolios.}

In the described strategy, we use ten assets: shares of Rosneft, MosBirzhi, AvtoVAZ up, Sberbank, LUKOIL, GAZPROM ao, Kamaz, Armada, Neftekamsk, MTS ao for the period from December 1, 2015 to December 2, 2016 with daily intervals.

At the moment $\mathrm{t} 2$ - the beginning of investment for the selected criterion, we have an array of assets ranked on the historical horizon. I carried the ranking out in descending order of the criterion values. We will call the first three assets in the ranked array "good", the last three - "bad". We construct equalweighted portfolios with the structure $x=\left(\begin{array}{lll}1 / 3 & 1 / 3 & 1 / 3\end{array}\right)$ T from the "good" and "bad" assets. We denote by wig, wib the capital at the ith moment of time of the portfolio of "good" and "bad" assets. To get the dynamics of the two portfolios, it is necessary to form a matrix of the returns of "good" and "bad assets" on the ownership interval, we denote them by $\mathrm{rg}$ and $\mathrm{rb}$, and the return of the portfolio of "good" assets and the return of the portfolio of "bad" assets will be got by the formulas $\operatorname{rpg}=\operatorname{rgx}, \mathrm{rpb}=\mathrm{rbx}$. The capital of two portfolios in the ownership interval is calculated by the formulas:

$$
\begin{aligned}
& w i+1 g=w i g(1+\text { rpig }), w 0 g=w 0, \\
& w i+1 b=w i b(1+r p i b), w 0 b=w 0,
\end{aligned}
$$

The following algorithm will obtain the optimal portfolio. After ranking the assets and dividing them into "good" and "bad", it solved two optimization problems. We found a portfolio structure of "good" assets that maximized the selected criterion, and of bad assets, we found a portfolio structure that minimized the criterion. Optimization problems were solved using decision blocks in MathCAD.

\section{Determination of the optimal parameter.}

The simulation period from December 1, 2015, to December 2, 2016, with a daily frequency of 255 days. Based on this, we can use the following values as parameters:

1) Historical horizon: 30, 50, 70, 90 days;

2) The starting point of ownership: 50,100, 150, 200 days.

We choose the parameters for each criterion, based on 4 conditions:

1) maximization of the average value of the investor income over the period of ownership;

2) maximization of the average income of the investor for the period of ownership;

3) maximization of the point value of investor income for the period of ownership;

4) maximization of the average point value of the investor income over the ownership period.

It turned out that, regardless of the criterion, the optimal parameter for creating a portfolio of securities is: the historical horizon - 30 days, while we assume that the beginning of ownership is 50 days.

\section{Portfolio reform.}

Portfolio reformation consists in the formation of the portfolio with a certain periodicity from the initial set of stocks to achieve maximum income. This procedure is:

1) An investment strategy begins with an analysis of the dynamics of assets.

we select Some criterion;

- For each asset, we get the criterion value;

- Assets are ranked by criterion value;

- "Good" and "bad" it highlights assets. 
2) At the beginning of each period, we selected a month, two portfolios are being built: one of the "good" shares, the other of the "bad" ones.

- Equal investments in both portfolios;

- Portfolio structure balanced.

3) The strategy for taking short and long positions is:

- Borrow the assets of the losers, sell them;

- We buy "good" shares for the amount received.

4) During the ownership period, in our case a month, the portfolio structure does not change.

5) At the end of the tenure, we sell a "good" portfolio and repay the debt.

The difference in the value of the portfolios at the end of the ownership period is our income, which can be positive or negative.

The reforming process (paragraph 1-5) continues $\mathrm{N}$ times, depending on the selected time and the specified parameters. For example, for the modeling period from December 1, 2015, to December 2,2016 , the historical horizon of 30 days, the beginning of ownership of 50 days and the period of ownership of 30 days, portfolio reformation can be performed 5 times.

Comparison of numerical results.

Because of modeling, they obtained the following arrays of investor income for the ownership period for various criteria:

Table 1.

\begin{tabular}{|c|c|c|c|c|c|c|}
\hline \multirow{2}{*}{ Initial moment } & \multicolumn{3}{|c|}{ Equally Weighted } & \multicolumn{3}{c|}{ Optimal } \\
\cline { 2 - 7 } & Mean & Sharpe & F-T & Mean & Sharp & F-T \\
\hline 50 & 0,04 & 0,04 & 0,04 & 0,071 & 0,125 & 0,125 \\
\hline 80 & 0,109 & 0,109 & 0,108 & 0,145 & 0,199 & 0,204 \\
\hline 110 & 0,157 & 0,204 & 0,156 & 0,323 & 0,34 & 0,313 \\
\hline 140 & 0,15 & 0,183 & 0,168 & 0,316 & 0,321 & 0,323 \\
\hline 170 & 0,146 & 0,183 & 0,165 & 0,327 & 0,321 & 0,306 \\
\hline 200 & 0,166 & 0,208 & 0,054 & 0,387 & 0,413 & 0,249 \\
\hline
\end{tabular}

The securities portfolio was formed and reorganized based on the smoothed, according to the Caterpillar method, stock prices. It shows the results below.

Table 2.

\begin{tabular}{|c|r|r|r|r|r|r|}
\hline \multirow{2}{*}{ Initial moment } & \multicolumn{3}{|c|}{ Equally Weighted } & \multicolumn{3}{c|}{ Optimal } \\
\cline { 2 - 7 } & \multicolumn{1}{|c|}{ Mean } & \multicolumn{1}{|c|}{ sharp } & \multicolumn{1}{|c|}{ F-T } & Mean & \multicolumn{1}{c|}{ Sharp } & F-T \\
\hline 50 & 0,04 & 0,098 & 0,04 & 0,031 & 0,058 & 0,031 \\
\hline 80 & 0,119 & 0,195 & 0,119 & 0,129 & 0,072 & 0,142 \\
\hline 110 & 0,155 & 0,287 & 0,155 & 0,335 & 0,125 & 0,227 \\
\hline 140 & 0,185 & 0,323 & 0,185 & 0,331 & 0,099 & 0,241 \\
\hline 170 & 0,03 & 0,182 & 0,03 & 0,206 & $-0,026$ & 0,045 \\
\hline 200 & $-0,03$ & 0,068 & $-0,03$ & 0,226 & $0,064,68^{*} 10^{\wedge}-3$ \\
\hline
\end{tabular}

As a result of the simulations, it turned out that the investor, investing in an equal-weighted securities portfolio, according to the Mean criterion, will receive an income equal to $16.6 \%$ of the initial funds, according to the Sharp criterion - 20.8\%, according to the Farinelli tibiletti criterion - $5.4 \%$ With optimal formation, the investor will receive a higher income of $38.7 \%, 4.13 \%, 24.9 \%$, respectively.

The smoothed data yielded a worse investment result: in an equal-weighted portfolio of securities, according to the criteria of Mean and Farinelli tibiletti, the investor will lose $3 \%$ of the invested funds, according to the Sharp criterion, he will receive 6.8. With optimal formation, the investor will receive an income of $22.6 \%, 6 \%$, less than $1 \%$, respectively.

Thus, we can say that when investing in the stocks of the companies selected by us, it is better to form an unbalanced (optimal) portfolio, using at the same time not smooth data and the Sharp criterion.

Conclusions. Investing securities is a difficult economic phenomenon, which comprises investing money in stocks to achieve profit or income. 
In theory, there are many ways, criteria, and strategies for investing, not depending on its occurrence, goals, manifestations and other factors, but they are very difficult to distinguish. All species intersect and flow into each other. However, generating income from investing in securities can be a manageable and controllable process. Which is one of the main factors of the socio-economic situation of a single subject and the country?

\section{REFERENCES}

1. Berdnikova TB Securities Market / T.B. Berdnikova. - M.: INFRA-M, 2002. - 277, [1] p .: ill.

2. Bocharov V.V. Investments: [textbook for high schools] / V.V. Bocharov. - 2nd ed. - SPb. [et al.]: Peter, 2008. - 380 p. - (Textbook for high schools). URL: http: //sun.tsu.ru/limit/2016/000241274/000241274.pdf.

3. Burenin A.N. Securities and derivatives market: Textbook / A.N. Burenin. - 2nd ed., Revised. and add. - M $\therefore$ Scientific-technical. island of them. S. I. Vavilova, 2002. - 351, [1] p .: graph .- (Series "Theory and Practice of the Financial Market").

4. Lyalin V.A. Securities Market: Textbook / V.A. Lyalin, P.V. Vorobiev. - Ed. 2nd, rev. and add. - Moscow: Prospect [et al.], 2011. - 398 pp., Ill.

5. Terpugov A.F. Mathematics of the securities market: a textbook for students of specialties 061800 Mathematical methods in economics, 010200 - Applied mathematics and computer science / A. F. Terpugov; Tom.gos. un-t - Tomsk: NTL Publishing House, 2004. - 162, [1] p.: Ill. - (Textbooks of Tomsk University). URL: http://vital.lib.tsu.ru/vital/access/manager/Repository/vtls: 000194194

6. Shapkin A.S. Securities Investment Portfolio Management / A.S. Shapkin, V.A. Shapkin. - 3rd ed. Moscow: Dashkov and Co., 2010. - 510, [1] p .: ill.

7. Sharp U. Investments / U.F. Sharp, G.J. Alexander, J.V. Bailey; Translation from English A.N. Burenina, A.A. Vasina. - M .: INFRA-M, 1997 .- 1025 p.: Ill.

8. How is an investment portfolio formed and what is portfolio investment [Electronic resource]. Electron.dan. - URL: http://kudainvestiruem.ru/klassifikatsiya/investicionnyj-portfel.html.

9. The official website of Finam [Electronic resource]. - Electron. dan. - URL: http: //www.finam.ru.

10. Formation of an investment portfolio [Electronic resource]. - Electron.dan. - URL: http://anokalintik.ru/investicionnyj-portfel.html. 